\title{
Free-riding and knowledge spillovers in teams: The role of social ties
}

\author{
Maria De Paola ${ }^{\mathrm{a}, 1}$, Francesca Gioia ${ }^{\mathrm{b}, \mathrm{c}, *}$, Vincenzo Scoppa ${ }^{\mathrm{a}, 2}$ \\ a Department of Economics, Statistics and Finance, University of Calabria, Italy \\ b School of Economics, University of Edinburgh, 30 Buccleuch Place, Edinburgh, EH8 9JT, UK \\ ${ }^{\mathrm{c}}$ Department of Law Cesare Beccaria, University of Milan, Via Festa del Perdono 7, Milano 20122, Italy
}

\section{A R T I C L E I N F O}

\section{Article history:}

Received 2 February 2018

Accepted 10 December 2018

Available online 18 December 2018

\section{JEL classification}

J33

$\mathrm{J} 24$

D82

D86

L14

C93

Keywords:

Team

Free-Riding

Knowledge Spillover

Social Ties

Randomized Field Experiment

\begin{abstract}
A B S T R A C T
We investigate whether and how social ties affect performance in teams by implementing a field experiment in which a sample of undergraduate students are randomly assigned either to teams composed by friends or to teams composed by individuals not linked by friendship relationships. Students undertake an intermediate exam divided into two parts: one graded on the basis of individual performance and the other graded on the basis of team performance. We find that students assigned to socially connected teams perform significantly better than control students in both the team part and the individual part of the exam, suggesting that social ties are relevant both for solving free-riding problems and for inducing knowledge spillovers among teammates. The positive effect of friendship persists over time: treated students obtain better grades also after the conclusion of the experiment.
\end{abstract}

(c) 2018 Elsevier B.V. All rights reserved.

\section{Introduction}

Teamwork is important in a number of different domains, such as business activities, research and sport. In many jobs production is carried out by groups of individuals who work in close collaboration. According to Bikfalvi et al. (2014), in Europe six out of ten manufacturers with more than 20 employees have implemented teamwork in production. Teamwork is pervasive also in the US with about $52 \%$ of firms relying on this type of work organization. Similarly, decision-making in many contexts is increasingly performed by teams rather than by individuals (Woolley et al., 2010; Hamilton et al., 2003).

Contract theory suggests that the use of pay schemes based on aggregate measures of performance, such as team output, generates free-riding behaviors that involve efficiency losses due to workers providing an amount of effort that is below the optimal level (Alchian and Demsetz, 1972; Holmstrom, 1982; Nalbantian and Schotter, 1997). Thus, a crucial feature of

\footnotetext{
* Corresponding author.

E-mail addresses: m.depaola@unical.it (M. De Paola), francesca.gioia@unimi.it, f.gioia@sms.ed.ac.uk (F. Gioia), v.scoppa@unical.it (V. Scoppa).

1 M. De Paola, Institute for the Study of Labor (IZA), Bonn, Germany.

2 V. Scoppa: Institute for the Study of Labor (IZA), Bonn, Germany.
} 
successful organizations implementing team incentives is the ability to overcome free-riding by designing effective monitoring schemes (Alchian and Demsetz, 1972), by using budget-breaking devices aimed at threatening potential free-riders (Holmström, 1982) or by establishing social norms that penalize opportunism (Corgnet et al., 2015; Kandel and Lazear, 1992; Mas and Moretti, 2009). These norms can be created through investments in corporate culture aimed at instilling a sense of belonging to a group of employees and at enhancing their preferences for cooperation. Peer pressure coming from various channels (desire to be liked or respected by teammates; sense of responsibility; fear of social punishment or feelings of guilt or shame) can also play an important role. The social cost of deviating from the cooperative norm is considered in the utility function of the individual, causing him/her to temper opportunistic behavior. This cost is related to the composition of the group (Towry, 2003; Reagans and Zuckerman, 2001; Spagnolo, 1999) and to the presence of social ties among team members (Babcock et al., 2015; Karlan, 2007; Balkundi and Harrison, 2006). Compared to strangers, friends may be able to better motivate and monitor each other and make social punishment more costly. Thus, being in a socially connected team may attenuate free-riding behaviour. Given the analogy between "output sharing" in a team and the public good game, a similar mechanism operates for public good games (see, for instance, Ledyard, 1995, and Chaudhuri, 2011). In addition, friends may be more likely to work together and interact to share information and knowledge. Then, an extra benefit of assigning friends to the same team is the enhancement of knowledge spillovers.

At the empirical level, the evidence on free-riding problems in teams is limited and with mixed results. While some studies document free-riding behaviour (Subramanian et al., 2017; Encinosa et al., 2007; van Dijk et al., 2001; Leibowitz and Tollison, 1980; Nalbantian and Schotter, 1997) others show an increase in productivity (Hamilton et al., 2003; Hansen, 1997) or no relevant difference compared to fixed pay schemes (Dohmen and Falk, 2011).

Since in real life situations individuals self-select in teams, it is difficult to disentangle the effect of social ties among team members on their performance from confounding factors such as, for instance, the impact of unobservable individual characteristics. Then, at the aim of providing evidence on the causal relationship between social ties and team performance, we have conducted a field experiment in which each participant is randomly assigned to a teammate who is a friend or, alternatively, to a teammate who is not socially connected with him/her.

Participants in our experiment are students enrolled at an Economics course in an Italian University. They were offered the possibility to join an alternative examination scheme allowing to split the exam into two tests: an intermediate test composed by one part evaluated on the basis of individual performance and another part whose evaluation was based on team performance, and a final test totally based on individual performance. A total of 260 students joined the experiment out of 274 students enrolled in the course. Students were firstly asked to name five friends among the students attending the same course and subsequently were randomly assigned to teams composed by two friends (treatment group) or to teams composed by two students not linked by friendship relationships (control group). Thus, the friendship relationships we exploit in the experiment consist in pre-existing ties among students rather than ties originating from team interactions. Since the course involved in the experiment is taught during the third year of university, students attending it had the opportunity to know each other in the past three years and establish friendships.

During the first week of classes, the composition of the different teams and the parts of the program evaluated respectively on the basis of individual and team performance (also randomly allocated) were communicated to students. In this way, teammates had time to work together and had all the information needed to decide how to allocate their studying effort.

Our experimental design allows us to investigate whether social ties help to reduce free-riding and create positive spillovers among teammates. While students had an incentive to free-ride at the part of the exam evaluated on the basis of team performance, there was no room for such an incentive for students' performance at the individual part of the exam. Since students knew in advance the parts of the course program included respectively in the individual and team part of the exam, we are able to distinguish between spillover and free-riding effects. If social ties are relevant exclusively to attenuate free-riding problems, we should find a positive effect on students' performance in team and no effect on the part of the intermediate test based on individual performance. Furthermore, if social ties also induce positive knowledge spillovers, since friends are more likely to work together and to share their knowledge, the effect of positive spillovers should spread across the two components of the intermediate test. Then, students belonging to a socially connected team should perform better than students belonging to teams not linked by social ties also in the part of the test evaluated on the basis of individual performance. If both channels are relevant, the effect of social ties on team performance should be higher than the effect produced on individual performance.

We find a positive and statistically significant effect of being part of a socially connected team on team performance: treated students obtain a grade of about 1 point higher than the grade obtained by control students (which represents an increase of about $18-20 \%$ in performance, about 0.33 Standard Deviations of the dependent variable). In addition, we find a positive and statistically significant effect on individual performance (about 0.7 points, corresponding to $11 \%$ ) that is nonetheless smaller than the effect found on the team part. This evidence suggests that social ties are relevant both for solving free-riding problems and, conditional on teammates having worked together, for enhancing positive spillovers among teammates. Furthermore, we show that the positive effect of friendship persists over time: treated students obtain better grades also in the final test based only on individual performance and taken after the conclusion of the experiment. 
We also study the consequences of ability heterogeneity among teammates and find some (weak) evidence that individuals without social ties tend to provide less effort when their own level of ability is different from their teammate's ability, while the effort of socially connected individuals does not depend on the ability of their teammate.

Our paper is related to the literature investigating the role of friendship among teammates and the optimal composition of teams. Hamilton et al. (2003) show that individuals might prefer to form teams with friends to enjoy the non-pecuniary benefits of working with them, while Bandiera et al. (2005) emphasize the opportunity given by friendship to reduce freeriding and enhance cooperation. Babcock et al. (2015) show that team incentives can outperform individual incentives in fostering students' attendance at a study hall in the library when being assigned to a known partner. An anonymous partner produces virtually the same effect of individual incentives, suggesting that knowledge of the partner plays an important role. They also find a smaller but similar effect in gym attendance. On the other hand, Bandiera et al. (2013) show that when incentives are stronger, because of team rankings or team tournaments, individuals are more likely to form teams with people with the same level of ability instead of choosing friends.

The paper is organized as follows. In Section 2 we describe our experimental design and in Section 3 we present the data. In Section 4 we carry out our main empirical analysis investigating students' performance in the team part of the test. Section 5 analyzes students' performance at the individual part of the test and in the final test. Section 6 discusses the effects produced by heterogeneous ability within each team. Section 7 concludes.

\section{Experimental design}

To investigate the effects of social ties on team performance, we ran a field experiment involving students enrolled in the academic year 2014-2015 at the course of Personnel Economics, offered by the First Level Degree Course in Business and Administration at the University of Calabria. ${ }^{3}$ The course was taught to students during the second semester (teaching period from February to May). (De Paola et al. 2018).

The standard exam of the course consisted of a single test on the whole program to be taken at the end of the course and evaluated on the basis of student's individual performance. During the first lecture of the course, in alternative to the standard exam, all enrolled students (274) were given the possibility to join an experimental examination scheme introducing teamwork and an alternative evaluation scheme. The experimental examination scheme was composed by two tests, each covering half of the program, to be taken right after the first half of the course (intermediate test) and at the end of it (final test), respectively. The intermediate test, with questions on the initial part of the course program (about 3 chapters of the textbook), was composed by two parts, one evaluated on the basis of individual performance ("the individual part") and the other evaluated on the basis of team performance ("the team part"). The individual part counted for $2 / 3$ of the total marks (students could gain a maximum of 20 points), while the remaining $1 / 3$ of the marks depended on team performance (students could gain a maximum of 10 points).

Students were assigned to teams of two members and each student's mark in the team part was the average of the points obtained by his/her team. The total score of the intermediate test of student $i$ was given by the sum of the marks obtained at the individual part and at the team part:

$$
\text { Grade Intermediate Test }{ }_{i}=\text { Grade Individual Part }_{\mathrm{i}}+\frac{\text { Grade Team Part }_{i}+\text { Grade Team Part }_{j}}{2}
$$

where student $j$ represents the teammate of student $i$.

The final test, to be taken at the end of the course to complete the exam in the experimental scheme, had questions on the second part of the course program and the evaluation was based only on individual performance with scores ranging from 0 to 30. The final exam grade in the experimental scheme was given by the average of the grades obtained in the intermediate and in the final test. ${ }^{4}$

We explained to students that they were absolutely free to join the experiment or to take the exam in the standard way. Furthermore, as required by the university for ethical reasons, students were made aware that, even if joining the experiment, they were free to leave it at any time (also after having taken the intermediate test) and to sit the standard exam, which was scheduled the same day as the final test.

Students were given five days to choose whether to sit the exam under the standard exam scheme or to join the experiment. In order to join the experiment students had to answer to an on-line survey proposing some questions on psychological attitudes, their network of friends and on their family background. In particular, we asked each student to name a maximum of five friends among students attending the course. Since the course considered is taught during the third year of university enrolment, students had almost three years to know each other and establish friendships.

\footnotetext{
3 The University of Calabria is a middle-sized public university located in the South of Italy. It has currently about 30,000 students enrolled in different Degree Courses and at different levels of the Italian University system. Since the 2001 reform, the Italian University system is organized around three main levels: First Level Degrees (3 years of legal duration), Second Level Degrees (2 years more) and Ph.D. Degrees. In order to gain a First Level Degree, students have to acquire a total of 180 credits. Students who have acquired a First Level Degree can undertake a Second Level Degree (acquiring 120 more credits). After having accomplished their Second Level Degree, students can enroll in a Ph.D. degree.

4 Only students reaching a final grade of at least 18 pass the exam. In the standard exam grades range from 0 to 30
} 
A total of 260 students joined the experiment and only 14 students among those enrolled in the course did not join. The very high participation rate (95\%) is probably due to both the possibility to subsequently leave without any cost and the opportunity to take an intermediate exam instead of taking a final exam covering the whole program. ${ }^{5}$

Students did not know ex-ante that one of the friends they named might be assigned as their teammate for the team part of the exam. The matching procedure was never communicated to the students.

Using the names of the friends provided by each student we created a list of potential couples with mutual correspondence, that is, we considered only couples where student $i$ named student $j$ as a friend and, at the same time, the latter named the former as a friend. We formed 678 mutual couples and assigned a random number $u$ to each couple. Then, we sorted couples on the basis of $u$ and assigned the treatment status to the students in the first 65 couples, that is, 130 students (we skipped couples where one of the students was already assigned previously). The remaining 130 students represent the control group: they were assigned randomly to 65 teams of two students. ${ }^{6}$

Since some parts of the course program might be more difficult than others, we divided the program into three sections (A, B, C) and randomly assigned section A to the individual part and section B to the team part for $50 \%$ of the teams, and assigned section $B$ to the individual part and section $A$ to the team part for the remaining 50\%. Section $C$ was assigned always to the individual part. Part A was on hiring decisions (optimal number of workers, optimal combination of different workers according to technology); part B was on training investments (general and specific training with perfect and imperfect labor markets) and part $\mathrm{C}$ was on signaling and screening schemes in hiring decisions.

Students were promptly informed of the team composition and the parts of the course program assigned to teamwork and to individual work. ${ }^{7}$ Students could study for the exam in the same way they are used to study for regular exams: individually, with friends, with students with similar or different ability. We could not force them to study together. However, we encouraged students to work in team and we required them to submit to the course's professor a number of exercises assigned to each team as homework during the course, although no specific incentive (penalty) was announced for teams accomplishing (not accomplishing) the task.

Both treated and control students attended the lectures in the same room, at the same time and with the same instructor and teaching material. After four weeks of classes students undertook the intermediate test. All students took the test with the same questions and at the same time. The test questions regarding both parts of the intermediate test were distributed simultaneously at the beginning of the test and students had $90 \mathrm{~min}$ to complete the whole test. Tests were marked and students were informed about the marks obtained: teaching assistants marking the tests had no information on whether students were assigned to the treatment or the control group.

At the end of the course, students either completed the exam under the experimental scheme by undertaking the final test or, alternatively, took the standard exam. In both these tests, students were evaluated exclusively on the basis of their individual performance.

\section{Data, descriptive statistics and balance checks}

We started with a sample of 260 students joining the experiment: 130 of them were "treated" and assigned to "socially connected teams" and the remaining 130 were in the control group and assigned to "no socially connected teams". The dummy variable Socially Connected Team identifies the treatment, that is students related by pre-existing ties rather than ties originating from team interactions.

Descriptive statistics are reported in Table 1. About $56 \%$ of students joining the experiment are females. Students are on average about 22 years old. High School Grade (ranging from 60 to 100) is on average about $85.58 \%$ of students joining the experiment have studied in a Lyceum. ${ }^{8}$ On average, students expect to obtain a grade of 25.5 at the exam (elicited in the online survey at the beginning of the course). Average parents' years of education is $11.7 .83 \%$ and $48 \%$ of fathers and mothers, respectively, are employed. Almost 50\% of students come from the same province in which the University is located.

As measures of social interactions, which could be correlated to some kind of abilities, for each student we calculated the number of friends named in our survey (\# Friends), the number of times other students named him/her (\# Received Nominations) and the number of mutual couples formed (\# Mutual Couples). The average number of friends named by students was 4.68 (the vast majority named the maximum of 5), students received on average 4.02 nominations, and each of them was part of 2.67 mutual couples. In our sample, all students had at least one mutual friend. The percentage of students with 1, 2, 3, 4 and 5 mutual friends are 25, 22.3, 22.7, 20.8 and 9.2, respectively. As regards the gender composition of the teams, $42 \%$ were composed by two females, $29 \%$ by two males and the remaining $29 \%$ were mixed couples.

\footnotetext{
${ }^{5}$ De Paola and Scoppa (2011) show that students benefit a lot from having the class program tested through an intermediate examination covering the first part of the course material and a final exam covering exclusively the second part instead of a single exam covering the whole program.

${ }^{6}$ In principle, students forming control couples could be still friends by chance, but no one in the control group turned out to be "friend" with his/her teammate.

${ }^{7}$ We informed students that if one of the students did not show up at the intermediate exam, in order to compute the score obtained in the team part of the test by his/her teammate we would replace the score of the absent student with the score of a randomly selected student with the same expected ability of the present teammate.

${ }^{8}$ In Italy, after lower secondary school pupils choose between a 'more academically oriented track' (Lyceum), or a more labor market-oriented track (Technical or Vocational Schools). Students coming from more educated families typically choose a Lyceum, while those from poorer socio-economic backgrounds tend to enroll in technical or vocational schools.
} 
Table 1

Descriptive statistics.

\begin{tabular}{llllll}
\hline Variable & Mean & Std. Dev. & Min & Max & Obs \\
\hline Socially connected team & 0.500 & 0.501 & 0 & 1 & 260 \\
Female & 0.562 & 0.497 & 0 & 1 & 260 \\
Age & 21.891 & 0.583 & 20.408 & 23.923 & 260 \\
High school grade & 85.496 & 9.159 & 66 & 100 & 260 \\
Lyceum & 0.581 & 0.494 & 0 & 1 & 260 \\
Expected grade & 25.546 & 2.253 & 18 & 31 & 260 \\
Section A in team & 0.515 & 0.501 & 0 & 1 & 260 \\
Parents' education & 11.683 & 3.188 & 2.5 & 18 & 260 \\
Father: employed & 0.835 & 0.372 & 0 & 1 & 260 \\
Mother: employed & 0.477 & 0.500 & 0 & 1 & 260 \\
Same area & 0.496 & 0.501 & 0 & 5 & 260 \\
\# Friends & 4.681 & 0.715 & 2 & 15 & 260 \\
\# Received nominations & 4.019 & 2.391 & 1 & 5 & 260 \\
\# Mutual couples & 2.669 & 1.303 & 1 & 1 & 260 \\
Female-Female & 0.415 & 0.494 & 0 & 1 & 260 \\
Female-Male & 0.146 & 0.354 & 0 & 1 & 260 \\
Male-Female & 0.146 & 0.354 & 0 & 1 & 260 \\
Male-Male & 0.292 & 0.456 & 0 & 10 & 260 \\
Present & 0.800 & 0.401 & 0 & 10 & 260 \\
Grade team part & 5.668 & 3.001 & 0 & 1 & 208 \\
Grade individual part & 6.171 & 2.807 & 0 & & 208 \\
Absent teammate & 0.135 & 0.342 & 0 & & 208 \\
\hline
\end{tabular}

Notes: Sample of students joining the experiment.

Table 2

Balance checks. Student characteristics across treatment and control groups.

\begin{tabular}{|c|c|c|c|c|c|c|c|c|}
\hline \multirow[t]{3}{*}{ Variable } & \multicolumn{4}{|c|}{ Panel (a). Joining the experiment } & \multicolumn{4}{|c|}{ Panel (b). Taking the exam } \\
\hline & (1) & (2) & (3) & $(4)$ & (5) & (6) & (7) & \\
\hline & Treated & Control & Diff. T-C & $p$-value & Treated & Control & Diff. T-C & $p$-value \\
\hline Female & 0.538 & 0.585 & -0.047 & 0.530 & 0.486 & 0.573 & -0.087 & 0.294 \\
\hline Age & 21.859 & 21.923 & -0.064 & 0.379 & 21.884 & 21.896 & -0.012 & 0.888 \\
\hline High school grade & 84.662 & 86.331 & -1.669 & 0.238 & 84.943 & 86.893 & -1.95 & 0.189 \\
\hline Lyceum & 0.562 & 0.600 & -0.038 & 0.568 & 0.590 & 0.641 & -0.05 & 0.509 \\
\hline Expected grade & 25.569 & 25.523 & 0.046 & 0.883 & 25.895 & 25.786 & 0.109 & 0.738 \\
\hline Section $A$ in team & 0.492 & 0.538 & -0.046 & 0.601 & 0.524 & 0.563 & -0.039 & 0.679 \\
\hline Parents' education & 11.692 & 11.673 & 0.019 & 0.962 & 11.490 & 11.777 & -0.286 & 0.541 \\
\hline Father: employed & 0.823 & 0.846 & -0.023 & 0.614 & 0.829 & 0.835 & -0.006 & 0.901 \\
\hline Mother: employed & 0.500 & 0.454 & 0.046 & 0.441 & 0.476 & 0.437 & 0.039 & 0.571 \\
\hline Same area & 0.477 & 0.515 & -0.038 & 0.599 & 0.457 & 0.495 & -0.038 & 0.643 \\
\hline \# Friends & 4.777 & 4.585 & 0.192 & 0.036 & 4.800 & 4.573 & 0.227 & 0.027 \\
\hline \# Received nominations & 3.885 & 4.154 & -0.269 & 0.412 & 4.162 & 4.515 & -0.353 & 0.321 \\
\hline \# Mutual couples & 2.623 & 2.715 & -0.092 & 0.605 & 2.743 & 2.854 & -0.112 & 0.546 \\
\hline Female-Female & 0.462 & 0.369 & 0.093 & 0.288 & 0.419 & 0.359 & 0.060 & 0.520 \\
\hline Female-Male & 0.077 & 0.215 & -0.138 & 0.000 & 0.067 & 0.214 & -0.147 & 0.001 \\
\hline Male-Female & 0.077 & 0.215 & -0.138 & 0.000 & 0.076 & 0.204 & -0.128 & 0.004 \\
\hline Male-Male & 0.385 & 0.200 & 0.185 & 0.020 & 0.438 & 0.223 & 0.215 & 0.016 \\
\hline Present & 0.808 & 0.792 & 0.015 & 0.789 & & & & \\
\hline Obs. & 130 & 130 & & & 105 & 103 & & \\
\hline
\end{tabular}

Notes: Panel (a): students joining the experiment; Panel (b): students effectively taking the exam.

Students were allowed to change their mind and switch back to the standard exam. Thus, even if almost all students (95\%) signed up to join the experiment, $52(20 \%)$ did not show up at the first test. Thus, 208 students took part to the first test: 105 in the "socially connected team" group and 103 in the "no socially connected team" group.

The performance of students at the team part (Grade Team Part) was on average 5.67 (ranging from 0 to 10) ${ }^{9}$ while the grade obtained at the individual part was 6.17 (we rescaled the grade at the individual part by dividing it by two to make it comparable with the grade of the team part). 28 students (13.5\%) were coupled with a student who did not show up at the test.

In Table 2 we report mean values separately by treatment groups, both for the sample of students joining the experiment (columns 1 and 2 ) and for those actually showing up at the intermediate test (columns 5 and 6 ) to verify that students are

\footnotetext{
${ }^{9}$ It is worth to clarify that our main dependent variable Grade Team Part represents the performance of the student at the team part of the exam and not the mark obtained in this part which is instead determined by the performance of both team members.
} 
successfully randomized both ex-ante and ex-post. Indeed, since we could not force students joining the experiment to effectively show up at the intermediate test, it could be that they self-selected in relation to their assigned teammate.

Differences in means between treatment and control are presented in column (3) ( $p$-values are reported in column 4) for the sample of students joining the experiment and in column (7) ( $p$-values in column 8) for the sample of students effectively taking the test. Results show that the randomization was successful in creating comparable treatment and control groups with regards to the observable characteristics: there are no significant differences between treated and control students in terms of gender, age, high school grade, type of high school attended and the grade they expect to obtain at the exam both when we consider the sample of students joining the experiment and when we look at the subsample of students actually showing up at the intermediate test. Only the difference in the number of friends (about 0.2 ) between treatment and control groups turns out to be statistically significant, while the differences in the number of received nominations and in the number of mutual couples formed are not different from zero.

Since students tend to name friends of their same gender, the percentage of teams with two males or two females is significantly higher in the group of "socially connected teams" than in the "no socially connected teams" group. The opposite is true for mixed gender teams. Treated couples tend to be prevailingly single-sex: $46 \%$ of treated couples are with two females (compared to 37\% in the control group) and 38\% are with two males (compared to $20 \%$ in the control group). To avoid any possible bias, we take this aspect into consideration by controlling for the gender composition of the couples in our estimates. ${ }^{10}$

In the Appendix (Table A1), we show that the decision to take the intermediate test is not affected by the assigned treatment group although it is affected by individual characteristics (females and lower ability students are more likely to not show up).

As students might reasonably expect that friends named in the survey could be used to form teams and then name them strategically, for instance on the basis of ability, we have analyzed which are the variables affecting nominations.

We have first investigated whether students choose to form teams with people with the same level of ability instead of choosing friends. We find that the correlation between the High School Grade of students and their first named friend is 0.21 statistically significant at the $1 \%$ level; this correlation becomes smaller and not statistically significant for the second and the third named friends $(0.10, p$-value $=0.19 ; 0.02, p$-value $=0.78)$ and is equal to 0.16 and 0.17 ( $p$-value $=0.05 ; p$ value $=0.08$ ) for the fourth and the fifth named friend respectively. This evidence suggests that even if there is a positive correlation among peers' abilities, participants in the experiment did not name their friends strategically.

Furthermore, we checked if friends are listed in order of ability. In the absence of information on how we would have treated named friends, it is reasonable to think that students could have predicted that the first named friend is more likely to be in the assigned team than the second named friend and so on. Therefore, if students listed friends strategically, one should find that friends are named in order of abilities. However, we find that there is no relationship between the high school grade of the friends and the order in which they are listed (the average High School Grade is more or less the same regardless of the order: first friend 86.47; second friend 87.66; third friend 85.68; fourth friend 86.16; fifth friend 87.41).

We also check if students named friends strategically exploiting the fact that for the Degree Program (Business and Economics) involved in our experiment all first years courses are organized in two different classes by dividing students into two groups depending on their surnames (A-L and M-Z). Given this rule, students take all the courses of the first year with the same group of peers and as a consequence this group of students has spent together a large amount of time (physically sitting in the same classroom). If students have named their friends not strategically but on the basis of the strength of their relationship (which should depend on the amount of time spent together), we would expect that students with surnames from A to L will especially name students with surnames from A to L, while students with surnames from $\mathrm{M}$ to $\mathrm{Z}$ are more likely to name students with surnames from $\mathrm{M}$ to $\mathrm{Z}$. We find clear evidence of this: $89.9 \%$ of students named as first friend a student who has attended first year classes in the same classroom. This percentage is equal to $83.6 \%$, $75.5 \% 71.6 \%$ and $62.9 \%$ respectively for friend $2,3,4$ and 5 , suggesting that the strength of the relationship is an important determinant of students' nominations. ${ }^{11}$

\section{Do Social Connections Help to Overcome Free-riding? Students' Performance at Teamwork}

The literature on teamwork and incentives suggests that evaluating and compensating individuals on the basis of team performance leads to free-riding, namely members of the team tend to not contribute or contribute less to team output and enjoy their share of teammates' performance (Alchian and Demsetz, 1972; Holmstrom, 1982; Nalbantian and Schotter, 1997). As shown in the Appendix (Table A2) we also find that students perform significantly worse when engaged in team work with respect to individual work. However, social ties may contribute to the attenuation of free-riding issues because friends

\footnotetext{
${ }^{10}$ We have also conducted our balance checks considering the multiple hypothesis testing proposed by List et al. (2016). We find that, when taking into account the multiplicity of the comparisons, the difference in the number of friends between treated and control groups is no longer statistically significant and the difference in the share of mixed gender teams becomes significant at the 5 percent level (instead of 1 percent).

${ }^{11}$ As students typically tend to establish friendship relationships with people of their own sex, we have also tried to understand whether nominations in our sample follow this rule. We find that $89.4 \%$ of students named as first friend a student of their own gender. This percentage is equal to 81.2, 75.6, 73.9, 74.7 respectively for the second, the third, the fourth and the fifth name indicated by students. This represents further suggestive evidence (admittedly not a proof) that friends are named on the basis of standard factors and not in a strategic way.
} 
Table 3

Social connections and team performance: OLS estimates.

\begin{tabular}{|c|c|c|c|c|c|c|}
\hline & $(1)$ & $(2)$ & $(3)$ & (4) & (5) & (6) \\
\hline Socially connected team & $\begin{array}{l}0.737 \\
(0.461)\end{array}$ & $\begin{array}{l}0.787^{*} \\
(0.458)\end{array}$ & $\begin{array}{l}1.052^{* * *} \\
(0.382)\end{array}$ & $\begin{array}{l}1.102^{* * *} \\
(0.378)\end{array}$ & $\begin{array}{l}1.221^{* * *} \\
(0.425)\end{array}$ & $\begin{array}{l}1.400^{* * * *} \\
(0.444)\end{array}$ \\
\hline Female & & $\begin{array}{l}0.734 \\
(0.454)\end{array}$ & $\begin{array}{l}0.149 \\
(0.406)\end{array}$ & $\begin{array}{l}0.063 \\
(0.395)\end{array}$ & & \\
\hline Section $A$ in team & & $\begin{array}{l}-0.220 \\
(0.460)\end{array}$ & $\begin{array}{c}-0.071 \\
(0.390)\end{array}$ & $\begin{array}{l}-0.037 \\
(0.399)\end{array}$ & $\begin{array}{l}0.010 \\
(0.401)\end{array}$ & $\begin{array}{l}0.039 \\
(0.398)\end{array}$ \\
\hline Age & & $\begin{array}{l}-0.447 \\
(0.313)\end{array}$ & $\begin{array}{l}-0.602^{* *} \\
(0.298)\end{array}$ & $\begin{array}{l}-0.545^{*} \\
(0.317)\end{array}$ & $\begin{array}{l}-0.563^{*} \\
(0.329)\end{array}$ & $\begin{array}{l}-0.557^{*} \\
(0.325)\end{array}$ \\
\hline High school grade & & & $\begin{array}{l}0.143^{* * *} \\
(0.018)\end{array}$ & $\begin{array}{l}0.145^{* * *} \\
(0.018)\end{array}$ & $\begin{array}{l}0.140^{* * *} \\
(0.019)\end{array}$ & $\begin{array}{l}0.142^{* * *} \\
(0.019)\end{array}$ \\
\hline Lyceum & & & $\begin{array}{l}1.008^{* *} \\
(0.406)\end{array}$ & $\begin{array}{c}1.097^{* *} \\
(0.435)\end{array}$ & $\begin{array}{l}1.083^{* *} \\
(0.436)\end{array}$ & $\begin{array}{c}1.101^{* *} \\
(0.436)\end{array}$ \\
\hline Expected grade & & & $\begin{array}{l}0.170^{*} \\
(0.094)\end{array}$ & $\begin{array}{l}0.175^{*} \\
(0.093)\end{array}$ & $\begin{array}{l}0.175^{*} \\
(0.093)\end{array}$ & $\begin{array}{l}0.167^{*} \\
(0.093)\end{array}$ \\
\hline Parents' education & & & & $\begin{array}{l}0.005 \\
(0.065)\end{array}$ & $\begin{array}{l}0.002 \\
(0.064)\end{array}$ & $\begin{array}{l}-0.008 \\
(0.065)\end{array}$ \\
\hline Father: employed & & & & $\begin{array}{l}1.265^{* *} \\
(0.519)\end{array}$ & $\begin{array}{l}1.238^{* *} \\
(0.534)\end{array}$ & $\begin{array}{c}1.258^{* *} \\
(0.534)\end{array}$ \\
\hline Mother: employed & & & & $\begin{array}{l}-0.734^{*} \\
(0.387)\end{array}$ & $\begin{array}{l}-0.711^{*} \\
(0.392)\end{array}$ & $\begin{array}{l}-0.680^{*} \\
(0.389)\end{array}$ \\
\hline Same area & & & & $\begin{array}{l}-0.491 \\
(0.428)\end{array}$ & $\begin{array}{l}-0.501 \\
(0.435)\end{array}$ & $\begin{array}{l}-0.532 \\
(0.433)\end{array}$ \\
\hline Absent teammate & & & & $\begin{array}{l}0.212 \\
(0.487)\end{array}$ & $\begin{array}{l}0.137 \\
(0.500)\end{array}$ & $\begin{array}{l}0.637 \\
(0.575)\end{array}$ \\
\hline Female-Female & & & & & $\begin{array}{l}0.397 \\
(0.494)\end{array}$ & $\begin{array}{l}0.407 \\
(0.495)\end{array}$ \\
\hline Female-Male & & & & & $\begin{array}{l}0.327 \\
(0.623)\end{array}$ & $\begin{array}{l}0.258 \\
(0.621)\end{array}$ \\
\hline Male-Female & & & & & $\begin{array}{l}0.959 \\
(0.673)\end{array}$ & $\begin{array}{l}0.966 \\
(0.676)\end{array}$ \\
\hline Absent Teammate*SociallyConnected Team & & & & & & $\begin{array}{l}-1.745^{*} \\
(1.024)\end{array}$ \\
\hline Constant & $\begin{array}{l}5.296^{* * *} \\
(0.280)\end{array}$ & $\begin{array}{l}14.787^{* *} \\
(6.931)\end{array}$ & $\begin{array}{l}0.946 \\
(7.181)\end{array}$ & $\begin{array}{l}-1.133 \\
(7.685)\end{array}$ & $\begin{array}{c}-0.650 \\
(8.145)\end{array}$ & $\begin{array}{c}-0.806 \\
(8.035)\end{array}$ \\
\hline Observations & 208 & 208 & 208 & 208 & 208 & 208 \\
\hline Adjusted $R$-squared & 0.010 & 0.020 & 0.231 & 0.252 & 0.254 & 0.258 \\
\hline
\end{tabular}

Notes: The Table reports OLS estimates. Dependent Variable: Grade at the team part. Standard errors (corrected for heteroskedasticity and allowed for clustering at the team level) are reported in parentheses. The symbols ${ }^{* * *}{ }^{* *},{ }^{*}$ indicate that the coefficients are statistically significant at the 1,5 and $10 \%$ level, respectively.

may be better able than unfamiliar persons to motivate and monitor each other and increase the social cost of deviating from cooperation.

Teamwork has also positive spillovers if teammates help each other and each teammate shares his/her knowledge with the group. Social ties may enhance positive spillovers if friends are more likely to work together in a cooperative environment and to share their knowledge.

If social ties are indeed beneficial to reduce free-riding and to generate positive spillovers, in our setting we would expect treated students (linked by mutual friendship) to perform better than control students in the team part of the test.

To provide evidence on these effects we estimate the following linear regression model:

$$
\text { Grade Team Part }{ }_{i}=\beta_{0}+\beta_{1} \text { Socially Connected Team } i+\beta_{2} X_{i}+\beta_{3} G_{i}+\beta_{4} S_{i}+\varepsilon_{i}
$$

where Grade Team Part ${ }_{i}$ is the dependent variable, that is, the performance of student $i$ at the part of the test assigned for teamwork; Socially Connected Team $m_{i}$ is a dummy variable taking the value of 1 when student $i$ is assigned to a team with one of his/her friends and 0 otherwise; $X_{i}$ denotes the vector of student's predetermined characteristics and cognitive ability (Female, Age, High School Grade, Expected Grade, Lyceum), a dummy variable for those students who are matched with a student who did not show up at the test (Absent Teammate), a dummy for the section of the course program evaluated on the basis of team performance (Section $A$ in Team), family background and Same Area; $G_{i}$ includes a vector of dummies to capture the gender composition of teams (Female-Female; Female-Male; Male-Female; male students coupled with a male teammate are left as reference category); $S_{i}$ includes three measures of student's social interactions (number of friends, received nominations and mutual couples formed); $\varepsilon_{i}$ is an error term.

Table 3 reports OLS estimates for the impact of being part of a socially connected team on students' performance at the team part. Our sample is represented by 208 students showing up at the intermediate test. In all the tables, standard errors are corrected for heteroskedasticity and allowed for clustering at the team level. 
In the first specification we only consider as a regressor the dummy variable Socially Connected Team and we find a positive and almost statistically significant relationship ( $p$-value $=0.11$ ) between being part of a socially connected team and student's performance at the team part: treated students obtain a grade +0.737 points higher than control students assigned to teams with no social connections.

The second specification adds among controls Female, Age and Section A in Team. The effect of Socially Connected Team is similar in magnitude $(+0.787)$ and significant at the $10 \%$ level while the additional controls are not significant. In column (3) we add some controls for students' abilities: High School Grade, Expected Grade and Lyceum. These variables are all positive and very significant: the R-squared jumps from 0.02 to 0.23 . The causal effect of social ties in this specification is +1.05 and it is significant at the $1 \%$ level.

In column (4) we control also for parents' education and employment status, for the residence of students and for the dummy Absent Teammate: the effect of the treatment is very similar $(+1.10)$. In column (5) we include also the three dummies for the gender composition of the team (excluding Female from our controls): while the gender composition of the team does not seem to affect performance ${ }^{12}$ (the F-test for the joint significance of these variables is 0.7 with a $p$-value of 0.55 ) the impact of being part of a socially connected team is still positive and statistically significant at the $1 \%$ level and larger in magnitude $(+1.22)$ compared with the specifications with fewer controls.

Finally, to investigate whether having a teammate who decided to not show up produces different effects for control and treated students, in column (6) we include among controls the interaction term Socially Connected Team*Absent Teammate. As expected, we find that socially connected teams have a larger effect $(+1.40)$ when a student's teammate is effectively present at the exam. On the other hand, the interaction term attracts a negative and statistically significant coefficient $(-1.74)$ : this implies that the positive effect of social connections completely vanishes $(-0.34, t$-stat $=-0.35)$ for students whose teammate does not show up at the exam (while an absent teammate does not produce any statistically significant effect on control students). This finding further confirms that socially connected teams generate a positive effect that cannot be realized when one of the student does not take part to the exam (and probably does not undertake joint studying activity ex-ante).

All in all, we find a strong effect of Socially Connected Team: considering that the average grade at the team part is 5.67, social connections increase performance of about $19 \%$ or 0.36 standard deviation of the dependent variable (considering column 4 of Table 3).

We have also performed separate regressions for males and females: although females seem to benefit slightly more from social connections (1.31 vs. 1.15) we do not find significant gender differences in response to treatment (results not reported).

We have also tested the role played by a number of non-cognitive abilities, such as risk and intertemporal preferences and an indicator of procrastination, which we measure using students' answers to specific questions included in the on-line survey and aimed at capturing these psychological traits. These controls are far from being statistically significant and do not affect our main results (estimates not reported).

A potential bias that could undermine the internal validity of our estimates arises from the fact that in our random assignment procedure students that reported a higher number of friends are more present in the list of potential couples and are more likely to be assigned to the treatment. This could create a correlation among our treatment and some unobservable individual characteristics and invalidate our estimates. As a matter of fact, we have shown in Table 2 that there was a statistically significant positive difference in the number of friends between treated and control groups.

In order to avoid this potential problem, firstly we simply control for our measures of social popularity. In Table 4 we investigate if students' "social popularity" affects their performance and if the treatment effect is robust with respect to these controls. In the first column we estimate the same specification as in column (5) of Table 3 adding controls for the number of friends reported in our survey, the number of received nominations and the number of mutual couples formed. None of these variables turns out to be significant while the impact of our treatment variable (and its statistical significance) is almost unchanged (+1.1). In columns (2)-(4) we control in turn for each of these variables separately, to avoid multicollinearity problems, since they are highly correlated. In all the specifications we do not find that these variables affect performance while we confirm that socially connected teams perform significantly better. ${ }^{13}$

In addition to the analysis carried out in Table 4, we focus on the sample of students with 5 friends and exclude all the others that reported a number of friends below the maximum. In this way, both treated and control students are "homogeneous" in terms of social connections. ${ }^{14}$ In columns (1) and (2) of Table 5 we run regressions (4) and (5) of Table 3 on this

\footnotetext{
12 The evidence on the effect of gender composition on team performance is mixed. While some studies find that teams formed by three women are significantly outperformed by all other gender combinations (Apesteguia et al., 2012), other papers find that teams with an equal gender mix perform better than male-dominated teams in terms of sales and profits (Hoogendoorn et al., 2013). In addition, some meta-analyses have shown either no effects or slightly negative effects for gender heterogeneity of team members on team performance (Jackson et al. 2003; Stewart 2006; Webber and Donahue, 2001).

13 The effect we find is unlikely to depend from differences in attendance rates among treated and control students. We have checked students' attendance randomly twice and the attendance rate was very high (around 90\%) and similar for the two groups.

14 This is confirmed by the fact that in this sample there are no statistically significant differences between treated and control students in terms of \# Received Nominations and in terms of \# Mutual Couples.
} 
Table 4

Social connections and team performance: controlling for the intensity of social relationships. OLS estimates.

\begin{tabular}{lllll}
\hline & $(1)$ & $(2)$ & $(3)$ & $(4)$ \\
\hline Socially connected team & $1.172^{* * *}$ & $1.143^{* * *}$ & $1.239^{* * *}$ & $1.240^{* * *}$ \\
& $(0.433)$ & $(0.431)$ & $(0.426)$ & $(0.427)$ \\
\# Friends & 0.338 & 0.405 & & \\
\# Received nominations & $(0.291)$ & $(0.264)$ & & \\
& 0.013 & & 0.067 & \\
\# Mutual couples & $(0.093)$ & & $(0.068)$ & 0.204 \\
& 0.135 & & & $(0.160)$ \\
Observations & $(0.235)$ & & & 208 \\
Adjusted R-squared & 208 & 208 & 208 & 0.257 \\
\hline
\end{tabular}

Notes: The Table reports OLS estimates. Dependent Variable: Grade at the team part. Controls as in specification (5) of Table 3. Standard errors (corrected for heteroskedasticity and allowed for clustering at the team level) are reported in parentheses. The symbols ${ }^{* * *},{ }^{* *},{ }^{*}$ indicate that the coefficients are statistically significant at the 1,5 and $10 \%$ level, respectively.

Table 5

Social connections and team performance. Sample: only students with five friends. OLS and Tobit estimates.

\begin{tabular}{|c|c|c|c|c|c|c|}
\hline & $\begin{array}{l}\text { (1) } \\
\text { OLS }\end{array}$ & $\begin{array}{l}\text { (2) } \\
\text { OLS }\end{array}$ & $\begin{array}{l}\text { (3) } \\
\text { OLS }\end{array}$ & $\begin{array}{l}(4) \\
\text { Tobit }\end{array}$ & $\begin{array}{l}\text { (5) } \\
\text { Tobit }\end{array}$ & $\begin{array}{l}\text { (6) } \\
\text { Tobit }\end{array}$ \\
\hline Socially connected team & $\begin{array}{l}0.747 \\
(0.451)\end{array}$ & $\begin{array}{l}0.816^{*} \\
(0.481)\end{array}$ & $\begin{array}{l}0.824^{*} \\
(0.484)\end{array}$ & $\begin{array}{l}1.054^{*} \\
(0.544)\end{array}$ & $\begin{array}{l}1.184^{* *} \\
(0.584)\end{array}$ & $\begin{array}{l}1.198^{* *} \\
(0.588)\end{array}$ \\
\hline Female & $\begin{array}{l}0.164 \\
(0.451)\end{array}$ & & & $\begin{array}{l}0.120 \\
(0.549)\end{array}$ & & \\
\hline Section A in team & $\begin{array}{l}-0.256 \\
(0.485)\end{array}$ & $\begin{array}{l}-0.229 \\
(0.493)\end{array}$ & $\begin{array}{l}-0.254 \\
(0.479)\end{array}$ & $\begin{array}{l}-0.413 \\
(0.585)\end{array}$ & $\begin{array}{l}-0.370 \\
(0.590)\end{array}$ & $\begin{array}{l}-0.380 \\
(0.577)\end{array}$ \\
\hline Age & $\begin{array}{l}-0.358 \\
(0.348)\end{array}$ & $\begin{array}{l}-0.398 \\
(0.356)\end{array}$ & $\begin{array}{l}-0.337 \\
(0.347)\end{array}$ & $\begin{array}{l}-0.442 \\
(0.407)\end{array}$ & $\begin{array}{l}-0.477 \\
(0.415)\end{array}$ & $\begin{array}{l}-0.393 \\
(0.411)\end{array}$ \\
\hline High school grade & $\begin{array}{l}0.136 \text { *** } \\
(0.022)\end{array}$ & $\begin{array}{l}0.131^{* * *} \\
(0.024)\end{array}$ & $\begin{array}{l}0.126 \text { *** } \\
(0.025)\end{array}$ & $\begin{array}{l}0.172^{* * * *} \\
(0.028)\end{array}$ & $\begin{array}{l}0.165^{* * *} \\
(0.029)\end{array}$ & $\begin{array}{l}0.160^{* * * *} \\
(0.030)\end{array}$ \\
\hline Lyceum & $\begin{array}{l}1.260^{* *} \\
(0.494)\end{array}$ & $\begin{array}{l}1.240^{* *} \\
(0.499)\end{array}$ & $\begin{array}{l}1.245^{* *} \\
(0.499)\end{array}$ & $\begin{array}{l}1.562 * * * \\
(0.597)\end{array}$ & $\begin{array}{l}1.538^{* *} \\
(0.599)\end{array}$ & $\begin{array}{l}1.536^{* * *} \\
(0.596)\end{array}$ \\
\hline Expected grade & $\begin{array}{l}0.196^{* *} \\
(0.096)\end{array}$ & $\begin{array}{l}0.196^{* *} \\
(0.097)\end{array}$ & $\begin{array}{l}0.197^{*} \\
(0.100)\end{array}$ & $\begin{array}{l}0.249 * * \\
(0.113)\end{array}$ & $\begin{array}{l}0.251^{* * *} \\
(0.114)\end{array}$ & $\begin{array}{l}0.261^{* *} \\
(0.117)\end{array}$ \\
\hline Parents' education & $\begin{array}{l}0.010 \\
(0.077)\end{array}$ & $\begin{array}{l}0.009 \\
(0.077)\end{array}$ & $\begin{array}{l}0.005 \\
(0.077)\end{array}$ & $\begin{array}{l}-0.010 \\
(0.093)\end{array}$ & $\begin{array}{l}-0.009 \\
(0.093)\end{array}$ & $\begin{array}{l}-0.011 \\
(0.091)\end{array}$ \\
\hline Father: employed & $\begin{array}{l}1.237^{* * *} \\
(0.560)\end{array}$ & $\begin{array}{l}1.208^{* *} \\
(0.568)\end{array}$ & $\begin{array}{l}1.162 * * \\
(0.576)\end{array}$ & $\begin{array}{l}1.591^{* *} \\
(0.676)\end{array}$ & $\begin{array}{l}1.568^{* * *} \\
(0.681)\end{array}$ & $\begin{array}{l}1.526^{* *} \\
(0.687)\end{array}$ \\
\hline Mother: employed & $\begin{array}{l}-0.489 \\
(0.448)\end{array}$ & $\begin{array}{l}-0.482 \\
(0.447)\end{array}$ & $\begin{array}{l}-0.475 \\
(0.455)\end{array}$ & $\begin{array}{l}-0.502 \\
(0.542)\end{array}$ & $\begin{array}{l}-0.484 \\
(0.538)\end{array}$ & $\begin{array}{l}-0.495 \\
(0.546)\end{array}$ \\
\hline Same area & $\begin{array}{l}-0.418 \\
(0.512)\end{array}$ & $\begin{array}{l}-0.443 \\
(0.519)\end{array}$ & $\begin{array}{l}-0.418 \\
(0.520)\end{array}$ & $\begin{array}{l}-0.549 \\
(0.615)\end{array}$ & $\begin{array}{l}-0.563 \\
(0.614)\end{array}$ & $\begin{array}{l}-0.540 \\
(0.612)\end{array}$ \\
\hline Absent teammate & $\begin{array}{l}-0.097 \\
(0.535)\end{array}$ & $\begin{array}{l}-0.143 \\
(0.541)\end{array}$ & $\begin{array}{l}-0.122 \\
(0.548)\end{array}$ & $\begin{array}{l}-0.190 \\
(0.584)\end{array}$ & $\begin{array}{l}-0.260 \\
(0.592)\end{array}$ & $\begin{array}{l}-0.230 \\
(0.588)\end{array}$ \\
\hline Female-Female & & $\begin{array}{l}0.462 \\
(0.567)\end{array}$ & $\begin{array}{l}0.537 \\
(0.582)\end{array}$ & & $\begin{array}{l}0.463 \\
(0.686)\end{array}$ & $\begin{array}{l}0.535 \\
(0.702)\end{array}$ \\
\hline Female-Male & & $\begin{array}{l}0.174 \\
(0.678)\end{array}$ & $\begin{array}{l}0.212 \\
(0.708)\end{array}$ & & $\begin{array}{l}0.349 \\
(0.783)\end{array}$ & $\begin{array}{l}0.361 \\
(0.810)\end{array}$ \\
\hline Male-Female & & $\begin{array}{l}0.742 \\
(0.740)\end{array}$ & $\begin{array}{l}0.787 \\
(0.743)\end{array}$ & & $\begin{array}{l}1.061 \\
(0.906)\end{array}$ & $\begin{array}{l}1.113 \\
(0.906)\end{array}$ \\
\hline \# Received nominations & & & $\begin{array}{l}0.112 \\
(0.111)\end{array}$ & & & $\begin{array}{l}0.102 \\
(0.133)\end{array}$ \\
\hline \# Mutual couples & & & $\begin{array}{l}-0.104 \\
(0.276)\end{array}$ & & & $\begin{array}{l}-0.038 \\
(0.315)\end{array}$ \\
\hline Observations & 166 & 166 & 166 & 166 & 166 & 166 \\
\hline Adjusted $R$-squared & 0.238 & 0.235 & 0.229 & & & \\
\hline Pseudo $R$-squared & & & & 0.074 & 0.076 & 0.077 \\
\hline
\end{tabular}

Notes: The Table reports OLS estimates (columns 1-3) and Tobit Estimates (marginal effects) (columns 4-6). Dependent Variable: Grade at the team part. We replicate specifications (4) and (5) of Table 3 and in columns (3) and (6) we estimate the specification in column (1) of Table 4. Standard errors (corrected for heteroskedasticity and allowed for clustering at the team level) are reported in parentheses. The symbols ${ }^{* * *},{ }^{* *},{ }^{*}$ indicate that the coefficients are statistically significant at the 1,5 and $10 \%$ level, respectively. 
Table 6

Social connections and team performance: heterogeneity by abilities. OLS estimates.

\begin{tabular}{|c|c|c|c|c|}
\hline & $\begin{array}{l}\text { (1) } \\
\text { First quartile }\end{array}$ & $\begin{array}{l}(2) \\
\text { Second and } \\
\text { third quartile }\end{array}$ & $\begin{array}{l}\text { (3) } \\
\text { Fourth quartile }\end{array}$ & $\begin{array}{l}(4) \\
\text { All }\end{array}$ \\
\hline Socially connected team & $\begin{array}{c}1.873^{* *} \\
(0.877)\end{array}$ & $\begin{array}{l}1.172 * \\
(0.610)\end{array}$ & $\begin{array}{l}0.520 \\
(0.784)\end{array}$ & $\begin{array}{l}1.129 * \\
(0.622)\end{array}$ \\
\hline Socially connected team*Q1 & & & & $\begin{array}{l}0.452 \\
(0.921)\end{array}$ \\
\hline Socially connected team*Q4 & & & & $\begin{array}{l}-0.500 \\
(0.878)\end{array}$ \\
\hline Observations & 53 & 103 & 52 & 208 \\
\hline Adjusted $R$-squared & 0.110 & 0.091 & 0.013 & 0.188 \\
\hline
\end{tabular}

Notes: The Table reports OLS estimates. We replicate the same specification reported in column (5) of Table 3. Standard errors (corrected for heteroskedasticity and allowed for clustering at the team level) are reported in parentheses. The symbols $* * *, * * *$ indicate that the coefficients are statistically significant at the 1,5 and 10\% level, respectively.

restricted sample (166 students) using an OLS estimator. We find qualitatively similar results: socially connected students tend to perform significantly better and the magnitude of the effect is slightly reduced with respect to the whole sample of students. The smaller effect of being in a socially connected team in this subsample may be due to the possibility to end up in a team with weaker social connections. In fact, while the first few named friends are likely to be close friends, as the number of nominations increases the friendship may be weaker. These results hold true also when, in column (3), we control for the intensity of social relationships (\# Received Nominations and \# Mutual Couples).

As shown in columns (4)-(6), very similar results are found also when we estimate a Tobit model, which takes into account the fact that grades are left censored at 0 and right censored at 10 (marginal effects of Tobit estimates turn out to be slightly larger than the OLS estimates).

The effect of being in a team with a friend may differ depending on the ability of the student. In particular, for low ability students, since the provision of effort is typically more costly and they need to study hard and to spend more time on the course material to pass the exam, a fully cooperative teammate might not make a significant difference. On the other hand, low ability students when in team with their friends might work hard to avoid producing a negative externality or because they take high ability friends as role models and work harder when in team with them. It could also be that these students take particular advantage from the help that they can get from their friends. On the opposite side, high ability students, as effort is not particularly costly for them, may easily put more effort in the team part of the exam when paired with a friend to help him/her getting a higher score on this part.

To examine the heterogeneous effects of social ties according to individual ability, we have undertaken a principal component analysis using our measures of individual ability High School Grade and Expected Grade in order to obtain a comprehensive measure of individual ability (only the first component was considered), which we call Ability. Then, we have divided our sample according to quartiles of abilities and replicated specification (5) of Table 3 separately for the first and the fourth quartile of the distribution of our variable Ability and for the second and third quartiles. Results are reported in Table 6.

We find that students from all levels of ability benefit from being matched with friends, but students in the first quartile of the ability distribution obtain a particularly high benefit. That is, students with the lowest ability benefit a lot from being paired with a friend: the effect is almost twice the effect for the other levels of ability. It is possible that low ability students work harder to avoid producing a negative externality on a friend. In addition, the fact that low-ability students benefit more from social connections could be caused by positive spillover effects, that are more likely to go from high-ability students towards low-ability students, rather than the other way around. However, these results have to be taken with caution as in column (4) of Table 6, in which we estimate on the whole sample using interaction terms, we find that the differences in the effect across quartiles are not statistically significant.

All in all, our estimates show that social ties improve students' performance in the team part of the test. It is worthwhile to clarify that, as the "team part" is essentially a part of the test that is still done individually but marked as the average of the two teammates' performance, these effects might be in principle the result of group incentives even in the absence of teamwork. The positive effect could be the result of either attenuated free-riding problems or, conditional on team members having studied together, positive spillovers among teammates or a combination of both.

We are inclined to think that students have worked together since the team activity that we encouraged lasted for one month (during the preparation for the exam). We formed teams at the beginning of the course and encouraged students to work in team requiring also to submit a number of exercises assigned as homework during the course. Especially the evidence on spillover effects (see below) corroborates this interpretation.

In the next section, by focusing on students' performance at the individual part, we try to understand if positive spillovers are actually enhanced by mutual friendship. 
Table 7

Social connections and students' performance at the individual part: OLS estimates.

\begin{tabular}{|c|c|c|c|c|c|c|}
\hline & $(1)$ & $(2)$ & (3) & $(4)$ & (5) & (6) \\
\hline Socially connected team & $\begin{array}{l}0.526 \\
(0.432)\end{array}$ & $\begin{array}{l}0.576 \\
(0.428)\end{array}$ & $\begin{array}{l}0.807^{* *} \\
(0.373)\end{array}$ & $\begin{array}{l}0.768^{* *} \\
(0.376)\end{array}$ & $\begin{array}{l}0.784^{* *} \\
(0.384)\end{array}$ & $\begin{array}{l}0.735^{*} \\
(0.389)\end{array}$ \\
\hline Section A in team & & $\begin{array}{l}-0.164 \\
(0.431)\end{array}$ & $\begin{array}{l}-0.044 \\
(0.384)\end{array}$ & $\begin{array}{l}-0.083 \\
(0.383)\end{array}$ & $\begin{array}{l}-0.080 \\
(0.390)\end{array}$ & $\begin{array}{l}-0.056 \\
(0.389)\end{array}$ \\
\hline Female & & $\begin{array}{l}0.750^{*} \\
(0.421)\end{array}$ & $\begin{array}{l}0.271 \\
(0.378)\end{array}$ & $\begin{array}{l}0.208 \\
(0.405)\end{array}$ & & \\
\hline Age & & $\begin{array}{l}-0.715^{* *} \\
(0.319)\end{array}$ & $\begin{array}{l}-0.859^{* * * *} \\
(0.314)\end{array}$ & $\begin{array}{l}-0.988^{* * *} \\
(0.315)\end{array}$ & $\begin{array}{l}-0.987^{* * *} \\
(0.329)\end{array}$ & $\begin{array}{l}-0.851^{* * *} \\
(0.294)\end{array}$ \\
\hline High school grade & & & $\begin{array}{l}0.122^{* * *} \\
(0.018)\end{array}$ & $\begin{array}{l}0.125^{* * * *} \\
(0.018)\end{array}$ & $\begin{array}{l}0.124^{* * *} \\
(0.019)\end{array}$ & $\begin{array}{l}0.125^{* * *} \\
(0.020)\end{array}$ \\
\hline Lyceum & & & $\begin{array}{l}0.881^{* *} \\
(0.376)\end{array}$ & $\begin{array}{l}1.123^{* * * *} \\
(0.414)\end{array}$ & $\begin{array}{l}1.122^{* * * *} \\
(0.416)\end{array}$ & $\begin{array}{l}1.134^{* * * *} \\
(0.408)\end{array}$ \\
\hline Expected grade & & & $\begin{array}{l}0.111 \\
(0.094)\end{array}$ & $\begin{array}{l}0.114 \\
(0.092)\end{array}$ & $\begin{array}{l}0.114 \\
(0.093)\end{array}$ & $\begin{array}{l}0.135 \\
(0.093)\end{array}$ \\
\hline Parents' education & & & & $\begin{array}{l}-0.114^{*} \\
(0.067)\end{array}$ & $\begin{array}{l}-0.114^{*} \\
(0.067)\end{array}$ & $\begin{array}{l}-0.099 \\
(0.067)\end{array}$ \\
\hline Father: employed & & & & $\begin{array}{l}0.657 \\
(0.498)\end{array}$ & $\begin{array}{l}0.657 \\
(0.509)\end{array}$ & $\begin{array}{l}0.793 \\
(0.501)\end{array}$ \\
\hline Mother: employed & & & & $\begin{array}{l}-0.500 \\
(0.372)\end{array}$ & $\begin{array}{l}-0.499 \\
(0.377)\end{array}$ & $\begin{array}{l}-0.565 \\
(0.379)\end{array}$ \\
\hline Same area & & & & $\begin{array}{l}0.095 \\
(0.396)\end{array}$ & $\begin{array}{l}0.096 \\
(0.397)\end{array}$ & $\begin{array}{l}0.105 \\
(0.402)\end{array}$ \\
\hline Absent teammate & & & & $\begin{array}{l}-0.313 \\
(0.526)\end{array}$ & $\begin{array}{l}-0.321 \\
(0.529)\end{array}$ & $\begin{array}{l}-0.352 \\
(0.528)\end{array}$ \\
\hline Female-female & & & & & $\begin{array}{l}0.235 \\
(0.498)\end{array}$ & $\begin{array}{l}0.251 \\
(0.521)\end{array}$ \\
\hline Female-male & & & & & $\begin{array}{l}0.258 \\
(0.581)\end{array}$ & $\begin{array}{l}0.243 \\
(0.611)\end{array}$ \\
\hline Male-female & & & & & $\begin{array}{l}0.100 \\
(0.568)\end{array}$ & $\begin{array}{l}0.157 \\
(0.593)\end{array}$ \\
\hline \# Friends & & & & & & $\begin{array}{l}0.280 \\
(0.279)\end{array}$ \\
\hline \# Received nominations & & & & & & $\begin{array}{l}-0.084 \\
(0.095)\end{array}$ \\
\hline \# Mutual couples & & & & & & $\begin{array}{l}0.302 \\
(0.212)\end{array}$ \\
\hline Observations & 208 & 208 & 208 & 208 & 208 & 208 \\
\hline Adjusted $R$-squared & 0.004 & 0.031 & 0.194 & 0.209 & 0.201 & 0.207 \\
\hline
\end{tabular}

Notes: The Table reports OLS estimates. Dependent Variable: Grade at the individual part. Standard errors (corrected for heteroskedasticity and allowed for clustering at the team level) are reported in parentheses. The symbols ${ }^{* * *},{ }^{* *},{ }^{*}$ indicate that the coefficients are statistically significant at the 1,5 and $10 \%$ level, respectively.

\section{Socially connected teams and individual performance}

Our experimental design does not allow us to understand whether students have effectively worked in teams: thus, we are not able to distinguish how much of the total effect of social ties on team performance comes from free-riding attenuation or from positive spillovers due to teammates studying together and interacting in preparing the test. However, while free-riding is possible only for team performance, the effect of positive spillovers spreads across the two components of the test because a better understanding of any part of the course program improves the understanding of the other parts. Thus, if social ties enhance positive spillovers among teammates, socially connected teams should perform better than no socially connected teams also in the individual part of the test.

To shed light on this aspect, we consider as dependent variable the score that students obtain at the individual part of the test. Results are reported in Table 7. In the first two specifications, in which we do not include controls for students' ability, we find a positive but not statistically significant effect of being part of a socially connected team $(t-s t a t=1.34)$. However, when we include among regressors our controls for individual ability and family background (columns 3 and 4), we find that students coupled with one of their friends perform significantly better than control students also at the individual part of the test $(+0.807, t$-stat $=2.16)$. In columns $(5)$ and $(6)$ we add controls for the gender composition of teams and controls for students' social popularity and the treatment effect remains almost unchanged in magnitude and statistical significance.

Overall, the effect of working in a socially connected team on students' performance in the individual part ranges from 0.5 to 0.8 (on a mean of 6.17 it implies an increase in individual performance of 8-13\%). As expected, the estimated effect of social ties on individual performance tends to be lower than the effect on team performance, being absent the component of 
Table 8

Social connections and individual performance: heterogeneity by abilities. OLS estimates.

\begin{tabular}{|c|c|c|c|c|}
\hline & $\begin{array}{l}\text { (1) } \\
\text { First quartile }\end{array}$ & $\begin{array}{l}\text { (2) } \\
\text { Second and } \\
\text { third quartile }\end{array}$ & $\begin{array}{l}\text { (3) } \\
\text { Fourth quartile }\end{array}$ & $\begin{array}{l}\text { (4) } \\
\text { All }\end{array}$ \\
\hline Socially connected team & $\begin{array}{l}1.971^{* * *} \\
(0.638)\end{array}$ & $\begin{array}{l}0.853 \\
(0.602)\end{array}$ & $\begin{array}{l}-0.380 \\
(0.842)\end{array}$ & $\begin{array}{l}0.859 \\
(0.593)\end{array}$ \\
\hline Socially connected Team*Q1 & & & & $\begin{array}{l}0.556 \\
(0.821)\end{array}$ \\
\hline Socially connected team* ${ }^{*} 4$ & & & & $\begin{array}{l}-1.041 \\
(0.856)\end{array}$ \\
\hline Observations & 53 & 103 & 52 & 208 \\
\hline Adjusted $R$-squared & 0.109 & 0.023 & 0.027 & 0.160 \\
\hline
\end{tabular}

Notes: The Table reports OLS estimates. We replicate the same specification reported in column 5 of Table 7. Standard errors (corrected for heteroskedasticity and allowed for clustering at the team level) are reported in parentheses. The symbols ${ }^{* * *},{ }^{* *},{ }^{*}$ indicate that the coefficients are statistically significant at the 1,5 and $10 \%$ level, respectively.

Table 9

The lasting effects of social connections: performance at the final test. OLS estimates.

\begin{tabular}{lllllll}
\hline & $(1)$ & $(2)$ & $(3)$ & $(4)$ & $(5)$ & $(6)$ \\
\hline Socially connected team & 0.574 & $0.693^{*}$ & $0.869^{* *}$ & $0.844^{* *}$ & $0.693^{* *}$ & $0.694^{*}$ \\
& $(0.375)$ & $(0.352)$ & $(0.335)$ & $(0.336)$ & $(0.348)$ & $(0.354)$ \\
Observations & 173 & 173 & 173 & 173 & 173 & 173 \\
Adjusted $R$-squared & 0.011 & 0.054 & 0.152 & 0.153 & 0.182 & 0.167 \\
\hline
\end{tabular}

Notes: The Table reports OLS estimates. Dependent Variable: Grade Final Test. Standard errors (corrected for heteroskedasticity and allowed for clustering at the team level) are reported in parentheses. The symbols ***, **, * indicate that the coefficients are statistically significant at the 1,5 and $10 \%$ level, respectively.

the effect due to the reduction in free-riding behavior and since students are not supposed to study together the individual part.

We have also investigated whether the effects of social ties on individual performance vary according to individual ability by dividing our sample according to quartiles of abilities and replicating specification 5 of Table 7 separately for the first and the fourth quartile of the distribution of our variable Ability and for the second and third quartiles. Results, reported in Table 8 , show that students in the first quartile of the ability distribution obtain the highest advantage. This result coupled with those discussed in the previous section imply that, when in team with their friends, low ability students might provide extra-effort in general (not only to reduce free riding) and/or benefit of positive spillover effects from high-ability students. Again, these results have to be taken with caution as in column (4) of Table 8, in which we estimate on the whole sample using interaction terms, we find that the differences in the effect across quartiles are not statistically significant.

Furthermore, we have run the same estimates as in Table 7 by considering as dependent variable the overall grade obtained at the intermediate test by students in teams where both members took the test: controlling for individual ability, being assigned to a socially connected team increases the grade at the intermediate test by about 14-16\% (see Appendix, Table A3).

The positive effect of social ties deriving from interactions in learning activities among team members may persist also when students are not required to perform in team anymore. This may happen because they realize that working together is beneficial and continue to interact in studying activities or because the knowledge acquired through interactions with teammates when preparing the intermediate test is useful also for studying the remaining part of the course program. To investigate this aspect we consider students' performance at the final test (covering the second part of the course program), although it was an individual test and was undertaken when our experiment was concluded. 173 students showed up at the final test, 88 belonging to the "socially connected team" group and 85 to the "no socially connected team" group.

As shown in Table 9, in which we replicate specifications of Table 7, the spillover effects of socially connected teams outlast the intermediate test: being assigned to a Socially Connected Team at the intermediate test affects students' performance also at the final test when they are evaluated exclusively on the basis of individual performance. The effect (ranging from 0.57 to 0.87 ) is generally statistically significant but smaller in magnitude compared to that found for students' performance at the intermediate test.

\section{The effects of ability heterogeneity among teammates}

As discussed by a number of recent papers, team performance might be affected by the composition of the team. In previous estimates we have already investigated the effects produced by the gender composition of teams. Another relevant 
Table 10

Heterogeneity in abilities among teammates and social connections: OLS estimates.

\begin{tabular}{|c|c|c|c|c|}
\hline & $\begin{array}{l}1 \text { ) } \\
\text { Control }\end{array}$ & $\begin{array}{l}(2) \\
\text { Treated }\end{array}$ & $\begin{array}{l}\text { (3) } \\
\text { Control }\end{array}$ & $\begin{array}{l}(4) \\
\text { Treated }\end{array}$ \\
\hline Ability & $\begin{array}{l}1.532^{* * * *} \\
(0.221)\end{array}$ & $\begin{array}{l}1.115^{* * *} \\
(0.297)\end{array}$ & $\begin{array}{l}1.478^{* * * *} \\
(0.267)\end{array}$ & $\begin{array}{l}0.911^{* * * *} \\
(0.294)\end{array}$ \\
\hline Ability higher than Peer & $\begin{array}{l}-1.371^{*} \\
(0.716)\end{array}$ & $\begin{array}{l}0.343 \\
(0.432)\end{array}$ & $\begin{array}{l}-1.236^{*} \\
(0.709)\end{array}$ & $\begin{array}{l}0.416 \\
(0.431)\end{array}$ \\
\hline Ability lower than peer & $\begin{array}{l}-0.874^{*} \\
(0.496)\end{array}$ & $\begin{array}{l}0.560 \\
(0.361)\end{array}$ & $\begin{array}{l}-0.692 \\
(0.441)\end{array}$ & $\begin{array}{l}0.555 \\
(0.406)\end{array}$ \\
\hline Section $A$ in team & $\begin{array}{l}-0.095 \\
(0.396)\end{array}$ & $\begin{array}{l}0.118 \\
(0.629)\end{array}$ & $\begin{array}{l}-0.152 \\
(0.391)\end{array}$ & $\begin{array}{l}-0.022 \\
(0.583)\end{array}$ \\
\hline Female & $\begin{array}{l}-0.436 \\
(0.495)\end{array}$ & $\begin{array}{l}0.104 \\
(0.585)\end{array}$ & & \\
\hline Age & $\begin{array}{l}-0.663 \\
(0.411)\end{array}$ & $\begin{array}{l}0.253 \\
(0.558)\end{array}$ & $\begin{array}{l}-0.349 \\
(0.377)\end{array}$ & $\begin{array}{l}0.348 \\
(0.591)\end{array}$ \\
\hline Lyceum & $\begin{array}{l}0.450 \\
(0.514)\end{array}$ & $\begin{array}{l}1.806^{* * *} \\
(0.663)\end{array}$ & $\begin{array}{l}0.455 \\
(0.500)\end{array}$ & $\begin{array}{l}1.951^{* * *} \\
(0.625)\end{array}$ \\
\hline Parents' education & $\begin{array}{l}0.173 * * \\
(0.078)\end{array}$ & $\begin{array}{l}-0.221^{* *} \\
(0.110)\end{array}$ & $\begin{array}{l}0.154^{* *} \\
(0.075)\end{array}$ & $\begin{array}{l}-0.242^{* *} \\
(0.115)\end{array}$ \\
\hline Father: employed & $\begin{array}{l}0.113 \\
(0.651)\end{array}$ & $\begin{array}{l}2.177^{* *} \\
(0.858)\end{array}$ & $\begin{array}{l}0.235 \\
(0.592)\end{array}$ & $\begin{array}{l}2.435^{* * *} \\
(0.847)\end{array}$ \\
\hline Mother: employed & $\begin{array}{l}-0.693 \\
(0.444)\end{array}$ & $\begin{array}{l}-0.263 \\
(0.662)\end{array}$ & $\begin{array}{l}-0.731 \\
(0.454)\end{array}$ & $\begin{array}{l}-0.100 \\
(0.686)\end{array}$ \\
\hline Same area & $\begin{array}{l}-0.720 \\
(0.494)\end{array}$ & $\begin{array}{l}-0.682 \\
(0.688)\end{array}$ & $\begin{array}{l}-0.848 \\
(0.521)\end{array}$ & $\begin{array}{l}-0.652 \\
(0.664)\end{array}$ \\
\hline Absent teammate & $\begin{array}{l}0.862 \\
(0.588)\end{array}$ & $\begin{array}{l}-1.115 \\
(0.928)\end{array}$ & $\begin{array}{l}0.739 \\
(0.559)\end{array}$ & $\begin{array}{l}-1.332 \\
(1.035)\end{array}$ \\
\hline Female-Female & & & $\begin{array}{l}0.071 \\
(0.655)\end{array}$ & $\begin{array}{l}0.112 \\
(0.643)\end{array}$ \\
\hline Female-Male & & & $\begin{array}{l}-0.929 \\
(0.671)\end{array}$ & $\begin{array}{l}2.679 * * * \\
(0.713)\end{array}$ \\
\hline Male-Female & & & $\begin{array}{l}0.555 \\
(0.658)\end{array}$ & $\begin{array}{l}1.831 \\
(1.164)\end{array}$ \\
\hline \# Friends & & & $\begin{array}{l}0.275 \\
(0.346)\end{array}$ & $\begin{array}{l}0.064 \\
(0.442)\end{array}$ \\
\hline \# Received nominations & & & $\begin{array}{l}0.028 \\
(0.108)\end{array}$ & $\begin{array}{l}0.195 \\
(0.211)\end{array}$ \\
\hline \# Mutual couples & & & $\begin{array}{l}0.437 \\
(0.298)\end{array}$ & $\begin{array}{l}-0.445 \\
(0.382)\end{array}$ \\
\hline Observations & 103 & 105 & 103 & 105 \\
\hline Adjusted $R$-squared & 0.289 & 0.223 & 0.330 & 0.254 \\
\hline
\end{tabular}

Notes: The Table reports OLS estimates. Dependent Variable: Grade at the team part. Standard errors (corrected for heteroskedasticity and allowed for clustering at the team level) are reported in parentheses. The symbols ${ }^{* * *},{ }^{* *}$, * indicate that the coefficients are statistically significant at the 1, 5 and $10 \%$ level, respectively.

dimension to investigate is team heterogeneity in terms of ability. According to Prat (2002) when the inputs provided by team members are complementary it is efficient to have team members of similar ability. On the other hand, if abler agents can impose high team production norms, and/or enable learning by less able members, heterogeneous teams can be efficient (Hamilton et al., 2003). Low ability agents might take high ability agents as role models and work harder when in team with them. It could also be that team heterogeneity in ability affects free-riding problems and the possibility to solve them through social pressure mechanisms.

Therefore, students' decisions about the amount of effort to provide in studying for the team part of the test may depend on their teammate's ability. Students paired with less able mates might either decide to devote less effort in studying for the part of the course program evaluated on the basis of team performance as they anticipate a poor performance of their mates, or might want to help their less able mates and decide to exert more effort in order to compensate for the poor results that their mates might obtain. Similarly, students paired with abler mates might either increase their studying effort to reciprocate the good performance expected from their mates or decide to free-ride. This is true both for treated and control students but treated students might react differently as they are supposed to care more about their mates.

To investigate how the heterogeneity in team members' ability affects team performance we use our comprehensive measure of individual ability, Ability, to build the variable Difference Ability computed as the difference between a student's own ability and his/her teammate's Ability. As students might react asymmetrically when they are less or more able than their teammate, we have created two variables: the first one, Ability Higher than Peer, is equal to Difference Ability when the student is more able than his peer (Difference Ability $>=0$ ) and 0 otherwise, while the other, Ability Lower than Peer, is 
equal to the absolute value of Difference Ability when individual ability is lower than peer's ability (Difference Ability $<0$ ) and 0 otherwise.

We have run separate regressions for treated and control students. As shown in columns (1) and (2) of Table 10, in which we control for a small set of variables, students in no socially connected teams tend to provide less effort both when their own level of ability is higher than that of their teammate $(-1.37)$ and when their ability is lower than his/her teammate $(-0.87)$. In contrast, our estimates show that the effort of socially connected individuals does not depend on their teammate's abilities. Similar results are found when we include as explanatory variables a larger set of controls (columns 3 and 4 ), but for students who are not socially connected the negative effect of being matched with a more able peer $(-0.69)$ becomes imprecisely measured $(p$-value $=0.122)$.

\section{Concluding remarks}

Teams and teamwork have been long used by firms, organizations and institutions. Although implemented to improve performance thanks to knowledge spillovers between teammates, pay schemes based on aggregate measures of performance, such as team output, generate free-riding behaviors that involve efficiency losses due to subjects exerting less effort than with individual incentives.

Thus, organizations willing to implement team incentives resort to different tools in order to attenuate the downside of free-riding, such as monitoring schemes, budget-breaking devices aimed at threatening potential free-riders or social norms that penalize opportunism. In this paper, we suggest that the choice of the team composition may be important too. In particular, assigning friends to the same team may be beneficial for the organization because friends may be able to motivate and monitor each other better, for instance by increasing the social cost of deviating from cooperation; furthermore, friends are more likely to actually work together and share information and knowledge.

With the aim of providing evidence on the causal relationship between social ties and team performance, not affected by self-selection issues, we have conducted a field experiment involving university students engaged in studying activities for a college course. We have thus observed individuals in a real life environment in which they have strong incentives to perform well. Our experimental design allows us to compare the performance of teams composed by friends with the performance of teams composed by individuals not linked by friendship relationships, both when performance is evaluated on the basis of the team output and when performance is evaluated on the basis of individual effort. All in all, the effects of friendship on performance that we find are quite large in magnitude: an increase of about $20 \%$ in the team part of the test (corresponding to about $0.33 \mathrm{SD}$ of the dependent variable) and $11 \%$ in the individual part (about $0.27 \mathrm{SD}$ ).

Since we could not force students to work with the assigned team members (neither we could force treated students to study with the assigned friend nor we could avoid control students to not study with their friends) and they probably worked also individually or with their traditional friends regardless of the team composition defined in the experiment, our estimates can be considered a sort of "Intention-to-Treat" effect (in which the estimated effect is diluted by partial compliance to the assigned experimental condition), while the average treatment effect is presumably somewhat larger.

As the team part of the test is done individually but marked as the average performance of the two teammates, we can also look at our findings on this part of the exam as group incentive effects that would emerge even in absence of teamwork. Nonetheless, our evidence suggests that social ties are relevant both for solving free-riding problems and for enhancing positive knowledge spillovers among teammates. Moreover, the positive effect of social ties coming from interaction in learning activities among team members persists also when students are not required to perform in team anymore.

The result that social connections improve teammates performance suggests that randomly assigned peer groups, typically exploited in the education literature on peer effects, might lead to small peer effects estimates by design.

Our findings support the widespread practice of letting people self-select into teams instead of imposing the colleagues with whom to work and point to the importance of investing in employees' relationships, for example by organizing social dinners or sport activities outside the working hours.

\section{Acknowledgements}

We are grateful to the Head of the Department of Business and Administration at the University of Calabria for allowing us to run the experiment. We would like to thank two anonymous referees, Massimiliano Bratti, Guido de Blasio, Marta De Phillips, Sabrina Giordano, Claudio Lucifora, Tommaso Luzzati, Silvia Marchesi, Nicola Meccheri, Paolo Naticchioni, Federica Origo, Laura Pagani, Michela Ponzo, Mauro Sylos Labini, Marco Tonello and seminar participants at the Universities of Calabria and Pisa, at the IWAEE 2016 Conference (Catanzaro) and at the 2016 AIEL Conference (Trento) for useful comments and suggestions. Francesca Gioia gratefully acknowledges financial support from Economic and Social Research Council.

\section{Supplementary materials}

Supplementary material associated with this article can be found, in the online version, at doi:10.1016/j.euroecorev.2018. 12.002 . 


\section{Appendix}

\section{Determinants of students' participation at the exam}

In this appendix we analyze the determinants of students' decision to show up at the intermediate test. This will serve also as a further check aimed at reassuring that randomization was successful in the subsample of students effectively taking part in the intermediate test. Estimation results from a linear probability model are reported in Table A1. We find that the decision to take the intermediate test is not affected by the assigned treatment group, and so "socially connected" individuals are no more likely to participate. In contrast, males, students with higher High School Grade or with a higher Expected Grade are significantly more likely to effectively participate in the experiment by sitting the intermediate test.

\section{Evaluating the impact of teamwork}

To investigate the effect that being evaluated according to an equal sharing rule rather than a piece-rate rule produces on students' performance we stack the data at the exam level and consider two observations for each student pertaining to his/her performance at the team part and at the individual part of the test, respectively. With this aim, we build the variable Grade, that takes the values of Grade Team Part for the performance at the team part and Grade Individual Part for students' performance at the individual part of the test. We create also the dummy variable Team for the part carried out under team incentives. We estimate a model for Grade and this allows us to compare the performance of students under the two different evaluation rules. This is possible since we assigned randomly to students the parts of the program to study

Table A1

Probability of taking part to the exam (after having joined the experiment).

\begin{tabular}{|c|c|c|c|c|}
\hline & (1) & $(2)$ & (3) & $(4)$ \\
\hline Socially connected team & $\begin{array}{l}0.015 \\
(0.057)\end{array}$ & $\begin{array}{l}0.025 \\
(0.055)\end{array}$ & $\begin{array}{l}0.034 \\
(0.050)\end{array}$ & $\begin{array}{l}0.012 \\
(0.054)\end{array}$ \\
\hline Female & & $\begin{array}{l}-0.125^{* *} \\
(0.053)\end{array}$ & $\begin{array}{l}-0.131^{* *} \\
(0.052)\end{array}$ & \\
\hline Age & & $\begin{array}{r}-0.005 \\
(0.043)\end{array}$ & $\begin{array}{l}0.022 \\
(0.043)\end{array}$ & $\begin{array}{l}0.022 \\
(0.043)\end{array}$ \\
\hline High school grade & & $\begin{array}{l}0.007^{* *} \\
(0.003)\end{array}$ & $\begin{array}{l}0.000 \\
(0.002)\end{array}$ & $\begin{array}{l}0.001 \\
(0.002)\end{array}$ \\
\hline Lyceum & & $\begin{array}{l}0.123^{* *} \\
(0.053)\end{array}$ & $\begin{array}{l}0.105^{*} \\
(0.053)\end{array}$ & $\begin{array}{l}0.104^{*} \\
(0.053)\end{array}$ \\
\hline Expected grade & & & $\begin{array}{l}0.053^{* * *} \\
(0.011)\end{array}$ & $\begin{array}{l}0.052^{* * *} \\
(0.011)\end{array}$ \\
\hline Parents' education & & & $\begin{array}{r}-0.008 \\
(0.008)\end{array}$ & $\begin{array}{c}-0.008 \\
(0.008)\end{array}$ \\
\hline Father: employed & & & $\begin{array}{l}0.005 \\
(0.068)\end{array}$ & $\begin{array}{l}0.006 \\
(0.068)\end{array}$ \\
\hline Mother: employed & & & $\begin{array}{l}-0.046 \\
(0.055)\end{array}$ & $\begin{array}{l}-0.046 \\
(0.055)\end{array}$ \\
\hline Same area & & & $\begin{array}{l}-0.074 \\
(0.049)\end{array}$ & $\begin{array}{l}-0.077 \\
(0.050)\end{array}$ \\
\hline Section $A$ in team & & & $\begin{array}{l}0.074 \\
(0.050)\end{array}$ & $\begin{array}{l}0.071 \\
(0.050)\end{array}$ \\
\hline \# Friends & & & $\begin{array}{l}-0.041 \\
(0.035)\end{array}$ & $\begin{array}{c}-0.044 \\
(0.035)\end{array}$ \\
\hline \# Received nominations & & & $\begin{array}{l}0.026^{* *} \\
(0.012)\end{array}$ & $\begin{array}{l}0.025^{* *} \\
(0.012)\end{array}$ \\
\hline \# Mutual couples & & & $\begin{array}{l}0.039 \\
(0.029)\end{array}$ & $\begin{array}{l}0.041 \\
(0.029)\end{array}$ \\
\hline Female-Female & & & & $\begin{array}{l}-0.165^{* * *} \\
(0.058)\end{array}$ \\
\hline Female-Male & & & & $\begin{array}{l}-0.202^{* *} \\
(0.088)\end{array}$ \\
\hline Male-Female & & & & $\begin{array}{c}-0.119 \\
(0.076)\end{array}$ \\
\hline Constant & $\begin{array}{l}0.792^{* * *} \\
(0.036)\end{array}$ & $\begin{array}{l}0.339 \\
(0.899)\end{array}$ & $\begin{array}{c}-0.956 \\
(1.039)\end{array}$ & $\begin{array}{l}-0.925 \\
(1.047)\end{array}$ \\
\hline Observations & 260 & 260 & 260 & 260 \\
\hline$R$-squared & 0.000 & 0.056 & 0.208 & 0.217 \\
\hline
\end{tabular}

Notes: The Table reports OLS estimates. The dependent variable is Present. Standard errors (corrected for heteroskedasticity and allowed for clustering at the team level) are reported in parentheses. The symbols ${ }^{* * *},{ }^{* *},{ }^{*}$ indicate that the coefficients are statistically significant at the 1,5 and $10 \%$ level, respectively. 
Table A2

A comparison of performance in team and at the individual part.

\begin{tabular}{|c|c|c|c|c|c|}
\hline & (1) & $(2)$ & (3) & $(4)$ & $(5)$ \\
\hline Team & $\begin{array}{l}-0.502^{* * *} \\
(0.144)\end{array}$ & $\begin{array}{l}-0.502^{* * *} \\
(0.144)\end{array}$ & $\begin{array}{l}-0.502^{* * *} \\
(0.145)\end{array}$ & $\begin{array}{l}-0.502^{* * *} \\
(0.146)\end{array}$ & $\begin{array}{l}-0.502^{* * *} \\
(0.146)\end{array}$ \\
\hline Section $A$ in team & $\begin{array}{l}-0.224 \\
(0.381)\end{array}$ & $\begin{array}{l}-0.100 \\
(0.338)\end{array}$ & $\begin{array}{l}-0.119 \\
(0.341)\end{array}$ & $\begin{array}{c}-0.098 \\
(0.343)\end{array}$ & $\begin{array}{c}-0.104 \\
(0.342)\end{array}$ \\
\hline Female & $\begin{array}{l}0.665^{*} \\
(0.379)\end{array}$ & $\begin{array}{l}0.142 \\
(0.335)\end{array}$ & $\begin{array}{l}0.069 \\
(0.336)\end{array}$ & & \\
\hline Age & & $\begin{array}{l}-0.722^{* *} \\
(0.293)\end{array}$ & $\begin{array}{l}-0.766^{* *} \\
(0.310)\end{array}$ & $\begin{array}{l}-0.793^{* *} \\
(0.313)\end{array}$ & $\begin{array}{l}-0.655^{* *} \\
(0.295)\end{array}$ \\
\hline High school grade & & $\begin{array}{l}0.126^{* * *} \\
(0.018)\end{array}$ & $\begin{array}{l}0.127^{* * * *} \\
(0.018)\end{array}$ & $\begin{array}{l}0.126^{* * *} \\
(0.019)\end{array}$ & $\begin{array}{l}0.126^{* * *} \\
(0.020)\end{array}$ \\
\hline Lyceum & & $\begin{array}{l}0.880^{* *} \\
(0.355)\end{array}$ & $\begin{array}{l}1.076^{* * *} \\
(0.370)\end{array}$ & $\begin{array}{l}1.073^{* * *} \\
(0.371)\end{array}$ & $\begin{array}{l}1.103^{* * *} \\
(0.361)\end{array}$ \\
\hline Expected grade & & $\begin{array}{l}0.154^{*} \\
(0.085)\end{array}$ & $\begin{array}{l}0.154^{*} \\
(0.083)\end{array}$ & $\begin{array}{l}0.149 * \\
(0.084)\end{array}$ & $\begin{array}{l}0.159 * \\
(0.085)\end{array}$ \\
\hline Parents' education & & & $\begin{array}{l}-0.063 \\
(0.058)\end{array}$ & $\begin{array}{c}-0.066 \\
(0.058)\end{array}$ & $\begin{array}{l}-0.053 \\
(0.058)\end{array}$ \\
\hline Father: employed & & & $\begin{array}{l}0.930^{* *} \\
(0.452)\end{array}$ & $\begin{array}{l}0.893^{*} \\
(0.460)\end{array}$ & $\begin{array}{c}1.026^{* *} \\
(0.457)\end{array}$ \\
\hline Mother: employed & & & $\begin{array}{l}-0.546 \\
(0.346)\end{array}$ & $\begin{array}{l}-0.527 \\
(0.350)\end{array}$ & $\begin{array}{l}-0.580 \\
(0.352)\end{array}$ \\
\hline Same area & & & $\begin{array}{l}-0.257 \\
(0.336)\end{array}$ & $\begin{array}{l}-0.285 \\
(0.341)\end{array}$ & $\begin{array}{l}-0.259 \\
(0.340)\end{array}$ \\
\hline Absent teammate & & & $\begin{array}{r}-0.340 \\
(0.455)\end{array}$ & $\begin{array}{r}-0.346 \\
(0.460)\end{array}$ & $\begin{array}{l}-0.365 \\
(0.462)\end{array}$ \\
\hline Female-Female & & & & $\begin{array}{l}0.218 \\
(0.418)\end{array}$ & $\begin{array}{l}0.304 \\
(0.434)\end{array}$ \\
\hline Female-Male & & & & $\begin{array}{l}-0.118 \\
(0.516)\end{array}$ & $\begin{array}{l}-0.031 \\
(0.538)\end{array}$ \\
\hline Male-Female & & & & $\begin{array}{l}0.197 \\
(0.539)\end{array}$ & $\begin{array}{l}0.281 \\
(0.553)\end{array}$ \\
\hline \# Friends & & & & & $\begin{array}{l}0.403 \\
(0.284)\end{array}$ \\
\hline \# Received nominations & & & & & $\begin{array}{l}-0.039 \\
(0.087)\end{array}$ \\
\hline \# Mutual couples & & & & & $\begin{array}{l}0.197 \\
(0.191)\end{array}$ \\
\hline Constant & $\begin{array}{l}5.940^{* * *} \\
(0.369)\end{array}$ & $\begin{array}{l}6.582 \\
(6.876)\end{array}$ & $\begin{array}{l}7.747 \\
(7.381)\end{array}$ & $\begin{array}{l}8.590 \\
(7.588)\end{array}$ & $\begin{array}{l}2.747 \\
(7.404)\end{array}$ \\
\hline Observations & 416 & 416 & 416 & 416 & 416 \\
\hline Adjusted $R$-squared & 0.015 & 0.205 & 0.224 & 0.222 & 0.233 \\
\hline
\end{tabular}

Notes: The Table reports OLS estimates. Standard errors (corrected for heteroskedasticity and allowed for clustering at the individual level) are reported in parentheses. The symbols $*^{* *}, *^{*}, *$ indicate that the coefficients are statistically significant at the 1,5 and 10\% level, respectively.

under individual and team work. OLS estimates are reported in Table A2. In all the specifications we consider the Team dummy and we control for Section A in Team to take into account any possible difference in the difficulty of different parts of the course program. In all the specifications we find that students perform significantly worse when engaged in team work with respect to individual work.

3. Effects of social connections on the overall grade of the intermediate test

Table A3 reports the effect produced by being part of a Socially Connected Team on the Grade Intermediate Test, the overall grade obtained by students at the intermediate test determined in the following way:

$$
\text { Grade Intermediate Test }{ }_{i}=\text { Grade Individual Part }_{i}+\frac{\text { Grade Team Part }_{i}+{\text { Grade } \text { Team }_{\text {Part }}}_{j}}{2}
$$

We consider only teams where both members showed up at the exam and find effects similar to those found on Grade Team Part and on the Grade Individual Part. 
Table A3

Social connections and students' performance at the intermediate test: OLS estimates.

\begin{tabular}{lllllll}
\hline & $(1)$ & $(2)$ & $(3)$ & $(4)$ & $(5)$ & $(6)$ \\
\hline Socially connected team & 1.635 & 1.793 & $2.665^{* *}$ & $2.734^{* *}$ & $2.924^{* *}$ & $2.761^{* *}$ \\
& $(1.351)$ & $(1.326)$ & $(1.125)$ & $(1.116)$ & $(1.190)$ & $(1.218)$ \\
Observations & 180 & 180 & 180 & 180 & 180 & 180 \\
Adjusted $R$-squared & 0.007 & 0.050 & 0.230 & 0.254 & 0.248 & 0.250 \\
\hline
\end{tabular}

Notes: The Table reports OLS estimates. Dependent variable: Total Grade Intermediate Test. Standard errors (corrected for heteroskedasticity and allowed for clustering at the team level) are reported in parentheses. The symbols $* * *,{ }^{* *}, *$ indicate that the coefficients are statistically significant at the 1,5 and $10 \%$ level, respectively.

\section{References}

Alchian, A., Demsetz, H., 1972. Production, information costs, and economic organization. Am. Econ. Rev. 62 (5), 777-795.

Apesteguia, J., Azmat, G., Iriberri, N., 2012. The impact of gender composition on team performance and decision making: evidence from the field. Manag. Sci. 58 (1), 78-93.

Babcock, P., Bedard, K., Charness, G., Hartman, J., Royer, H., 2015. Letting down the team? Evidence of social effects of team incentives. J. Eur. Econ. Assoc. 13 (5), 841-870.

Balkundi, P., Harrison, D., 2006. “Ties, leaders, and time in teams: strong inference about network structure's effects on team viability and performance. Acad. Manag. J. 49 (1), 49-68.

Bandiera, O., Barankay, I., Rasul, I., 2013. Team incentives: evidence from a firm level experiment. J. Eur. Econ. Assoc. 11 (5), $1079-1114$.

Bandiera, O., Barankay, I., Rasul, I., 2005. "Social preferences and the response to incentives: evidence from personnel data. Q. J. Econ. 120, 917-962.

Bikfalvi, A., Jäger, A., Lay, G., 2014. The incidence and diffusion of teamwork in manufacturing-evidences from a Pan-European survey. J. Organ. Change Manag. 27 (2), 206-231.

Chaudhuri, A., 2011. Sustaining cooperation in laboratory public goods experiments: a selective survey of the literature. Exp. Econ. 14 (1), 47-83.

Corgnet, B., Hernán-González, McCarter, M., 2015. The role of the decision-making regime on cooperation in a workgroup social dilemma: an examination of cyberloafing. Games 6 (4), 588-603.

De Paola, M., Scoppa, V., 2011. Frequency of examinations and student achievement in a randomized experiment. Econ. Educ. Rev. 30 , $1416-1429$.

De Paola, M., Gioia, F., Scoppa, V., 2018. Data for: Free-Riding and Knowledge Spillovers in Teams: The Role of Social Ties. Mendeley Data, v1http://dx.doi.org/10.17632/54mhwwxvbm.1.

Dohmen, T., Falk, A., 2011. Performance pay and multidimensional sorting: productivity, preferences, and gender. Am. Econ. Rev. 101 (2), $556-590$.

Encinosa, W.E., Gaynor, M., Rebitzer, J.B., 2007. The sociology of groups and the economics of incentives: theory and evidence on compensation systems. J. Econ. Behav. Organ. 62 (2), 187-214.

Hamilton, B., Nickerson, J., Owan, H., 2003. Team incentives and worker heterogeneity: an empirical analysis of the impact of teams on productivity and participation. J. Polit. Econ. 111, 465-497.

Hansen, D.G., 1997. Worker performance and group incentives: a case study. Ind. Labor. Relat. Rev. 51 (1), $37-49$.

Holmstrom, B., 1982. "Moral hazard in teams. Bell J. Econ. 13 (2), 324-339.

Hoogendoorn, S., Oosterbeek, H., Van Praag, M., 2013. The impact of gender diversity on the performance of business teams: evidence from a field experiment. Manag. Sci. 59 (7), 1514-1528.

Jackson, S.E., Joshi, A., Erhardt, N.L., 2003. Recent research on team and organizational diversity: SWOT analysis and implications. J. Manag. 29 (6), 801-830.

Kandel, E., Lazear, E., 1992. Peer pressure and partnerships. J. Polit. Econ. 100, 801-813.

Karlan, D., 2007. Social connections and group banking. Econ. J. 117 (517), F52-F84.

Ledyard, J., 1995. "Public goods: a survey of experimental research. In: Kagel, John H., Roth, Alvin E. (Eds.), Handbook of experimental economics. Princeton University Press, Princeton, NJ.

Leibowitz, A., Tollison, R., 1980. Free-riding, shirking and team production in legal partnerships. Econ. Inq. 18, 380-394.

List, J.A., Shaikh, A.M., Xu, Y., 2016. Multiple hypothesis testing in experimental economics. Natl. Bureau Econ. Res. working paper n²1875.

Mas, A., Moretti, E., 2009. Peers at work. Am. Econ. Rev. 99 (1), 112-145.

Nalbantian, H., Schotter, A., 1997. Productivity under group incentives: an experimental study. Am. Econ. Rev. 87 (3), $314-341$.

Prat, A., 2002. "Should a team be homogeneous? Eur. Econ. Rev. 46, 1187-1207.

Reagans, R., Zuckerman, E., 2001. Networks, diversity, and productivity: The social capital of corporate R\&D teams. Organ. Sci. 12 (4), $502-517$.

Spagnolo, G., 1999. “Social relations and cooperation in organizations. J. Econ. Behav. Organ. 38 (1), 1-25.

Stewart, G.L., 2006. A meta-analytic review of relationships between team design features and team performance. J. Manag. 32 (1), 29-54.

Subramanian, K., Tantri, P., Bhowal, S., 2017. Free-riding in Teams. Mimeo.

Towry, K., 2003. "Control in a teamwork environment-the impact of social ties on the effectiveness of mutual monitoring contracts. Acc. Rev. 78 (4), 1069-1095.

Van Dijk, F., Sonnemans, J., Van Winden, F., 2001. Incentive systems in a real effort experiment. Eur. Econ. Rev. 45 (2), $187-214$.

Webber, S., Donahue, L., 2001. Impact of highly and less job-related diversity on work group cohesion and performance: a meta-analysis. J. Manag. 27, 141-162.

Woolley, A., Chabris, C., Pentland, A., Hashmi, N., Malone, T., 2010. “Evidence for a Collective Intelligence Factor in the Performance of Human Groups. Science 330 (6004), 686-688. 